\title{
Potential therapeutic use of the ketogenic diet in autism spectrum disorders
}

\author{
Eleonora Napoli ${ }^{1}{ }^{*}$, Nadia Dueñas $^{1}$ and Cecilia Giulivi ${ }^{1,2}$ \\ 1 Department of Molecular Biosciences, University of California Davis, Davis, CA, USA \\ ${ }^{2}$ Medical Investigations of Neurodevelopmental Disorders (M. I. N. D.) Institute, Sacramento, CA, USA
}

\section{Edited by:}

Roberto Canitano, University Hospital of Siena, Italy

Reviewed by:

Richard Eugene Frye, Children's Hospital Boston/Harvard University, USA

Daniel Rossignol, Rossignol Medical Center, USA

*Correspondence:

Eleonora Napoli, Department of Molecular Biosciences, University of California Davis, One Shields Avenue, Davis, CA 95616, USA

e-mail:enapoli@ucdavis.edu
The ketogenic diet (KGD) has been recognized as an effective treatment for individuals with glucose transporter 1 (GLUT1) and pyruvate dehydrogenase (PDH) deficiencies as well as with epilepsy. More recently, its use has been advocated in a number of neurological disorders prompting a newfound interest in its possible therapeutic use in autism spectrum disorders (ASD). One study and one case report indicated that children with ASD treated with a KGD showed decreased seizure frequencies and exhibited behavioral improvements (i.e., improved learning abilities and social skills). The KGD could benefit individuals with ASD affected with epileptic episodes as well as those with either PDH or mild respiratory chain $(\mathrm{RC})$ complex deficiencies. Given that the mechanism of action of the KGD is not fully understood, caution should be exercised in ASD cases lacking a careful biochemical and metabolic characterization to avoid deleterious side effects or refractory outcomes.

Keywords: epilepsy, autism spectrum disorders, dietary intervention, mitochondria, bioenergetics, ketogenic diet, oxidative stress

\section{BIOCHEMISTRY OF THE KGD}

The ketogenic diet (KGD) is a nutritional approach constituted by high-fat content with adequate protein amount for growth but insufficient levels of carbohydrates for metabolic needs (1), thus forcing the body to primarily use fat as a fuel source. The original KGD was designed as 4:1 lipid:non-lipid (carbohydrate plus protein) ratio with $80 \%$ fat, $15 \%$ protein, and $5 \%$ carbohydrate. Most of the fat is provided as long-chain triglycerides, composing $~ 80 \%$ of the estimated caloric dietary requirement (2). To date, several modifications to the original KGD have been introduced such as lowering the lipid:non-lipid ratio (3) and decreasing the caloric intake from fat $(\sim 60-70 \%)$ with either no restriction in calorie amount with unlimited protein and fat intake (modified Atkins diet) $(4,5)$, or with fat provided as triglycerides esterified with medium-chain fatty acids (FA) (to overcome deficits in carnitine metabolism; medium-chain triglyceride diet) (6).

The hormonal changes associated with a KGD include changes in circulating insulin (due to insulin reduction in response to decreasing plasma glucose) and/or leptin (7-9), thus limiting glucose utilization. Under normal conditions, FA mobilized from adipose tissue are catabolized to acetyl coenzyme A ( $\mathrm{CoA}$ ) via $\beta$-oxidation, and then oxidized to $\mathrm{CO}_{2}$ and $\mathrm{H}_{2} \mathrm{O}$ in the Krebs' cycle. However, when an imbalance is created between the rate of FA mobilization and the capacity of the Krebs' cycle to process acetylCoA (e.g., low-carbohydrate and/or protein diet), the liver converts the excess of acetylCoA into ketone bodies (KB), namely acetoacetate (ACA) and D- $\beta$-hydroxybutyrate (BHB). A significant fraction of acetone $(\sim 30 \%)$, the product of the spontaneous decarboxylation of ACA, is found in urine, sweat, and breath $(10,11)$. KB are utilized as fuel by peripheral tissues sparing glucose and muscle wasting. They generate a comparable amount of energy to protein or carbohydrates ( $2.7 \mathrm{vs.} 4 \mathrm{kcal} / \mathrm{g}$ ) and, unlike $\mathrm{FA}, \mathrm{KB}$ can cross the blood-brain barrier (12) constituting the main fuel sources for the brain during fasting periods (13). Most ATP from BHB is via Complex I (70-80\%), with the rest via Complex II (14). The lowcarbohydrate intake forces the body to sustain systemic glycemia by hepatic gluconeogenesis from non-carbohydrate precursors (e.g., lactate, glucogenic amino acids, and glycerol).

At the center of intermediary metabolism reside mitochondria. These dynamic organelles whose morphology, composition, and function adapt to changes in response to pathological and physiological signals respond to nutritional variations such as those introduced by KGD. Several reports in the literature document changes in mitochondrial number or function in a variety of biological systems, from in vitro to in vivo, when exposed to KGD or KGD-mimetics (Table 1).

\section{THERAPEUTIC USE OF THE KETOGENIC DIET IN HUMAN DISEASES}

By providing alternative sources of acetylCoA, KGD is the dietary intervention for inborn genetic disorders in pyruvate dehydrogenase (PDH) and glucose transporter 1 (GLUT1) (Table 1), proven effective also in other metabolic conditions, including phosphofructokinase deficiency and glycogenosis type $\mathrm{V}$ (McArdle disease) (37). The KGD has also been investigated for the management of neurological disorders such as Alzheimer's and Parkinson's diseases (38).

Ketogenic diet has been utilized for $>80$ years in epilepsy treatment $(39,40)$ especially in children and adolescents $(1,41)$ with reduction in seizure frequencies $(2,42)$ and improvements in developmental progress (26).

Evidence supporting the use of the KGD for patients with intractable epilepsy and respiratory chain (RC) complex defects has been reported in which the majority of patients responded with decreased seizure frequencies, regardless of the RC complex defect or magnitude of deficit (27). The administration of KGD 
Table 1 | Examples extracted from the literature on effects of KGD on mitochondrial function with the potential to benefit ASD symptoms

\begin{tabular}{|c|c|c|c|}
\hline Experimental model & Diet/treatment & KGD-dependent effects & Source \\
\hline \multicolumn{4}{|c|}{ OUTCOMES RELATEDTO ENERGY RESERVES AND/OR ENERGY-SENSING PATHWAYS } \\
\hline Rat hippocampus & Young rats fed KGD for 9 weeks & $\begin{array}{l}\text { Increased gene expression of mt genes; } \\
46 \% \text { increase in mitochondria number with } \\
\text { no changes in citrate synthase or any other } \\
\text { mt enzymatic activity; [PCr]/[Cr] higher (due } \\
\text { to lower [Cr]) }\end{array}$ & Bough et al. (15) \\
\hline Rat hippocampus & Young rats fed KGD for 1 month & $\begin{array}{l}\text { Decreased ( }-30 \%) \text { body weight than } \\
\text { controls; few mt genes overexpressed }\end{array}$ & Noh et al. (16) \\
\hline Rat brain & Fed HFD for 3 weeks & $\begin{array}{l}{[\mathrm{ATP}] /[\mathrm{ADP}] \text { increased by } 12 \% \text {; lower }[\mathrm{Cr}]} \\
\text { with no changes in }[\mathrm{PCr}] \text {; lower [cAMP] and } \\
{[\mathrm{cGMP}]}\end{array}$ & DeVivo et al. (17) \\
\hline Rat hippocampus & $\begin{array}{l}\text { Slices from rat hippocampus } \\
\text { ( } 4-7 \text { weeks) with } \mathrm{BHB} \text { and } \mathrm{ACA} \\
\text { each at } 0.5 \text { or } 1 \mathrm{mM}\end{array}$ & $\begin{array}{l}\text { KB prevented rotenone- and 3NP-dependent } \\
\text { decrease in ATP and decreased } \\
\text { 3NP-dependent ROS production }\end{array}$ & Kim do et al. (18) \\
\hline Mouse brain & $\begin{array}{l}\text { Mice (8-10 weeks) treated with } \\
\text { d-BHB or I-BHB via pumps }\end{array}$ & $\begin{array}{l}\text { BHB restored NADH-supported } \mathrm{O}_{2} \\
\text { consumption inhibited by } \mathrm{MPP}^{+} \text {, partly the } \\
\text { one inhibited by rotenone; } \mathrm{BHB}^{\text {increased }} \\
\text { mtROS. } 70-80 \% \text { ATP from } \mathrm{BHB} \text { produced } \\
\text { via Complex I, the remaining via Complex II }\end{array}$ & Tieu et al. (19) \\
\hline Rats & CR-KGD for 7 days & $\begin{array}{l}\text { Body weight loss, increased brain expression } \\
\text { of IGFR and GLUT3 }\end{array}$ & Cheng et al. (14) \\
\hline Neuronal human SH-SY5Y cell line & $\begin{array}{l}\text { FA (C8 or } \mathrm{C} 10) \text { treatment for } \\
1-6 \text { days }\end{array}$ & $\begin{array}{l}\text { Increased citrate synthase and Complex I } \\
\text { activities }\end{array}$ & Hughes et al. (20) \\
\hline Rat hippocampus and liver & $\begin{array}{l}\text { Rats fed with a 6:1 lipid:non-lipid } \\
\text { KGD }\end{array}$ & $\begin{array}{l}\text { Delayed occurrence of epileptic episodes via } \\
\text { mTOR inhibition }\end{array}$ & McDaniel et al. (21) \\
\hline
\end{tabular}

\begin{tabular}{|c|c|c|c|}
\hline \multicolumn{4}{|c|}{ OUTCOMES RELATEDTO NEUROLOGICAL SYMPTOMS/BEHAVIOR WITH RC COMPLEX AND/OR PDH DEFICIENCIES } \\
\hline Child with Leigh syndrome & KGD & $\begin{array}{l}\text { Improvement of cerebral lesions by brain } \\
\text { MRI }\end{array}$ & Wijburg et al. (22) \\
\hline Child, idiopathic PDH deficiency & $\begin{array}{l}\text { KGD for } ~ 3 \text { years (lipid:non-lipid 3:1 } \\
\text { later switched to } 2: 1 \text { ) }\end{array}$ & $\begin{array}{l}\text { Seizure free; improvement in hypotonia, } \\
\text { motor development, relationship with } \\
\text { environment; poor weight gain, high } \\
\text { ketonemia }\end{array}$ & Di Pisa et al. (24) \\
\hline Children with PDHE1 mutations & $\begin{array}{l}\text { KGD (varied degrees of } \\
\text { carbohydrate restriction) }\end{array}$ & Improved longevity and mental development & Wexler et al. (25) \\
\hline Child with PHDX & $\begin{array}{l}\text { KGD (lipid:non-lipid 4:1, later } \\
\text { switched to 3:1 plus MCT oil) }\end{array}$ & $\begin{array}{l}\text { Weight gain, decreased seizure episodes, } \\
\text { improved sociability and activity }\end{array}$ & El-Gharbawy et al. (26) \\
\hline
\end{tabular}

\section{OUTCOMES RELATEDTO MITOCHONDRIAL ANTIOXIDANT DEFENSES AND ROS}

Mouse hippocampus
Young mice fed a 6:1 lipid:non-lipid KGD for 10-12 d
Decreased mtROS; increases in UCP expression
Sullivan et al. (28) 


\section{Table 1 | Continued}

\begin{tabular}{lll}
\hline Experimental model & Diet/treatment & KGD-dependent effects \\
\hline Rat hippocampus & Adolescent rats, KGD (78\% lipid, & KGD-induced initial mild oxidative stress, \\
& $\begin{array}{l}0.76 \% \text { carbs) for 1, 3 days or 1, } \\
3 \text { weeks }\end{array}$ & Milder et al. (29) \\
Rat cortex, cerebellum, and & Adolescent rats fed with KGD or & Increased GPX activity and [GSH] \\
hippocampus & BHB for 3 weeks & \\
Rat neocortical neurons & Neurons exposed to BHB in vitro & $\begin{array}{l}\text { Decreased Glu-mediated excitotoxicity } \\
\text { mtROS production via increased NADH }\end{array}$
\end{tabular}

\section{OUTCOMES RELATEDTO MITOCHONDRIA-DERIVED NEUROTRANSMITTER METABOLISM}

$\begin{array}{ll}\text { Mouse forebrain } & \begin{array}{l}\text { Ketotic mice fed KGD (50\% lipids) } \\ \text { for } 3 \text { days }\end{array} \\ \text { Cerebrospinal fluid } & \begin{array}{l}26 \text { children with refractory epilepsy } \\ \text { fed KGD for } 6 \text { months }\end{array} \\ \text { Zebrafish with PDHE1 mutation, } & \text { Larvae fed a mix of } \\ \text { lower acetylcholine in inner retina } & \text { lauric/myristic/palmitic acid, and } \\ & \text { phosphatidyl choline } \\ \text { SSDAH mouse model } & \text { At PND 12 were fed KGD for } \\ & 20-30 \text { days }\end{array}$

Increased GABA and GIn production

Yudkoff et al. (33)

Increased [GABA], [taurine], [Ser], and [Gly]. Higher [GABA] (>50-90\% seizure reduction)

KGD rescued vision and prolong survival

Maurer et al. (35)

Increased mitochondrial number and size;

Nylen et al. (36) increased (ATP), no changes in lifespan or neurological outcomes

3-NP, 3-nitropropionic acid; AHA, acetoacetate; BHB, $\beta$-hydroxybutyrate; CR-KGD, calorie-restricted ketogenic diet; Cr, creatine; Gln, glutamine; Glu, glutamate; Gly, glycine; GPX, glutathione peroxidase; FA, fatty acids; HFD, high-fat diet; IGFR, insulin-like growth factor receptor; Mt, mitochondrial; MCT, medium-chain triglycerides; Nrf2, Nuclear factor-like 2; $P C r$, phospho-creatine; $P N D$, post-natal day; Ser, serine.

to epileptic patients $(37,39)$ has been based on the assumption that $\mathrm{KB}$ replace glucose as the major metabolic fuel to the brain, although the precise molecular steps still remain obscure. It has been proposed that $\mathrm{KB}$ metabolism is not the primary mechanism of this diet, but rather an outcome of the metabolic shifts that occur with this treatment (43) and that the anticonvulsant effects of the KGD could result from an altered gene expression profile accompanied by cellular adaptation mechanisms (15) needed to modify the brain to utilize KB over glucose over time (39).

\section{THERAPEUTIC USE OF KGD IN ASD}

Autism spectrum disorders (ASD) include a complex neurodevelopmental condition characterized by abnormal social interaction, verbal and non-verbal communication, and limited interest in the surrounding environment associated with stereotyped and repetitive behaviors (44). Limited scientific advances have been made regarding the causes of ASD, with general agreement that both genetic and environmental factors contribute to this disorder (4447). ASD has been associated to metabolic dysfunction $(44,48)$ and autism is a common trait of epilepsy-associated diseases (49), and syndromes like Landau-Kleffner, Dravet $(50,51)$, and Rett $(52,53)$. Thus, given the beneficial effects of KGD on epilepsy and increased mitochondrial function, its use has the potential to ameliorate some of the ASD-associated symptoms.

Beneficial effects of KGD in children with ASD symptoms have been reported in two independent studies $(54,55)$. The first study evaluated the role of KGD on 30 ASD children (54). The John
Radcliffe diet (a modified medium-chain triglyceride diet with a caloric distribution of $30 \%$ in medium-chain triglyceride oil, $30 \%$ fresh cream, $11 \%$ saturated fat, $19 \%$ carbohydrates, and $10 \%$ proteins) was administered for 6 months, with intervals of 4 weeks interrupted by two diet-free weeks. Of the 30 children, $40 \%$ did not comply or did not tolerate the diet. From the rest, the two children with the milder autistic behaviors showed the most improvement (as judged by total Childhood Autism Rating Scale score, concentration and learning abilities, and social behavior and interactions), while the rest displayed mild to moderate improvements. Interestingly, the beneficial effects of KGD persisted even after termination of the trial. Six of the children enrolled in this study had a higher baseline ketonemia with no apparent PDH and/or RC deficiencies; but it is not clear if any of the other patients underwent this screening, before and/or after the administration of the diet in addition to the lack of the inclusion of a control diet before administering the KGD to the ASD group or during the trial.

The other study (55) reports the administration of a gluten-free casein-free modified KGD (1.5:1 lipid:non-lipid ratio; mediumchain and polyunsaturated FA) for 14-months to a 12-year-old child with ASD and seizures with substantial medical comorbidities associated with a family history of metabolic and immune disturbances. Due to the improvements in seizure activity, improved electroencephalogram, cognitive and social skills, language function, and complete resolution of stereotypies, anticonvulsant medication doses were reduced without worsening of seizures. Of note, the administration of the diet was accompanied by a wealth of 
medications, a significant weight loss, and transitioning to puberty, so it is difficult to assess the sole role of the diet with this clinical background.

In mouse models of ASD [i.e., Rett syndrome (56), BTBR model (57), and succinate semialdehyde dehydrogenase (SSADH) deficiency (36)], the use of the KGD has improved behavioral abnormalities (increased sociability and decreased self-directed repetitive behavior) and/or decreased the number of seizures, normalized ataxia, and increased lifespan of mutant mice. However, while the KGD was originally designed to be administered under controlled caloric intake (38), most of the mouse studies have been performed under ad libitum conditions and/or for a relatively short period [see Ref. (57)]. Moreover, a ketogenic lowcarbohydrate diet does not have a significant metabolic advantage over a non-ketogenic low-carbohydrate diet as judged by equal effects in body weight reduction and decreased insulin resistance; however, the former one was associated with higher inflammatory risk and increased perception of fatigue (58).

Although the exact molecular mechanisms underlying the effect of the KGD are still under investigation, several scenarios are reported below to explore the potential therapeutic effects of the KGD in ASD.

\section{KGD IN PDH DEFICIENCY}

Peripheral blood mononucleated cell (PBMC) from children with high severity scores for ASD has shown impaired PDH activity (44). The KGD is recommended as an alternative source of the acetylCoA in patients (37) with pathogenic mutations in $\mathrm{PDH}$ - or GLUT1-encoding genes $(22,25)$ leading to amelioration of some symptoms $(59,60)$ especially in those with milder phenotypes $(25$, 61). Thus, the use of the KGD in ASD with PDH deficiencies might prove to be beneficial.

\section{KGD IN $\beta$-OXIDATION DEFECTS}

Some patients with ASD have been reported to have defects in fatty acid $\beta$-oxidation evidenced as long-chain acyl dehydrogenase deficiency (62) and high concentrations of short or long acyl-carnitines in plasma (63). Carnitine biosynthesis has been recently identified as a risk factor for ASD (64). Thus in these cases, it is advisable to limit the use of a high-fat diet or improve its safety by switching to short or medium-chain FA, which do not utilize the carnitine system.

\section{KGD IN MITOCHONDRIAL BIOGENESIS}

The KGD might improve mitochondrial function by enhancing mitochondrial biogenesis in murine models $(15,65)$. The medium-chain triglyceride diet (6) has been shown to produce significant increases in citrate synthase and Complex I activity in SH-SY5Y neurons (20). However, the increases in mitochondrial mass would need to result in an OXPHOS outcome of $\geq 30 \%$ [ $30 \%$ as the limit for minor diagnostic criteria of mitochondrial RC disorder (66)] for that particular tissue, given that each tissue has a different ATP threshold (67). Otherwise the increases in mass might not be sufficient to rescue the already impaired ATP production in ASD individuals. Moreover, given the presence of mitochondrial DNA (mtDNA) deletions in PBMC from $\operatorname{ASD}(44,68,69)$, the KGD-driven mitochondrial biogenesis may result in an enrichment of defective mitochondria due to the proliferating advantage of damaged or deleted mtDNA over wildtype $(70,71)$. Conversely, treatment of cells containing large-scale mtDNA deletions from a patient with Kearns-Sayre syndrome with $\mathrm{KB}$ shifted the heteroplasmy between and within cells (72). The observation that $\mathrm{KB}$ can distinguish between normal and respiration-compromised cells suggests that the $\mathrm{KB}$ may be useful in treating patients with heteroplasmic mtDNA disorders (72).

\section{ROLE OF THE KGD IN RC COMPLEX DEFICITS}

Children with ASD display an array of mitochondrial dysfunction (MD) of differing severity $(44,73-75)$. Electron transport chain (ETC) deficiencies have been reported in ASD, primarily in Complex I and IV, but also affecting others such as Complex II, III, and IV $(44,73,74,76)$. The prevalence of seizures $(41 \%)$ has been observed to be significantly higher in individuals with ASD and MD than in the general ASD population (11\%) (74), raising the possibility that epileptic episodes observed in ASD might have a mitochondrial origin. Indeed, epilepsy is a recurrent feature of many inherited "classic" mitochondrial disorders, like myoclonic epilepsy with ragged red fibers, mitochondrial encephalopathy with lactic acidosis, and stroke-like episodes (77), and Leigh syndrome (78). In a small study on children with ETC defects (Table 1), the KGD has been proven to reduce epileptic attacks, with far better prognosis among children with Complex I deficits than Complex IV (27). These results are not surprising given that KGD generates more NADH/FADH 2 than glucose (2 vs. 5 ).

\section{EFFECT OF KGD ON ENERGY-SENSING PATHWAYS ALTERATIONS}

Recently, KGD-fed rats showed increased brain expression of insulin-like growth factor receptor (ILGFR) and neuronal GLUT3 (14). The KGD might have a beneficial effect in some ASD cases considering that IGFR is important for brain health throughout life (79-81), and that IGFR and GLUT3 have both been implicated in $\operatorname{ASD}(82,83)$.

Some energy-sensing molecules and metabolism regulators (including the mammalian target of rapamycin, mTOR) have been recently indicated as possible downstream targets of KGD and may be involved in neuroprotective effects associated to the diet (84). Defects in the mTOR pathway have been linked to ASD (8587). Failure to inhibit mTOR pathway could lead to MD due to decreased mitophagy (88) resulting in an accumulation of dysfunctional mitochondria as observed in a mouse model of ASD with phosphatase and tensin homolog on chromosome ten (Pten) gene haploinsuffciency (89). Indeed, inhibition of mTOR has been linked to a delay in the occurrence of the epileptic episodes (90) and KGD-fed rats showed inhibition of the activation of the mTOR pathway in brain (21), thus representing an appropriate treatment to control seizures while enhancing the clearance of defective/damaged mitochondria.

\section{ANTIOXIDANT AND NEUROPROTECTIVE ROLE OF THE KGD}

Ketone bodies (without glucose and at concentrations 10-times higher than physiological ones) inhibit mitochondrial reactive oxygen species (ROS) production in rat neurocortical neurons by increasing NADH oxidation following glutamate (Glu) excitotoxicity (32). It has been suggested that the production of NADPH via 
oxidation of succinate semialdehyde (SSA) into succinate in the Glu decarboxylase (GAD) $/ \gamma$-aminobutyric acid (GABA) pathway may buffer the redox changes likely to occur in stressful conditions (91-93). However, other mitochondrial NADPH sources are quantitatively more important than SSADH and fatty acid oxidation produces more mitochondrial ROS than pyruvate oxidation (94).

Thus, the use of KGD could be beneficial in ASD given that higher rates of mitochondrial ROS production and compromised cellular antioxidant status $(69,95,96)$ have been reported in peripheral cells from children with $\operatorname{ASD}(44,68,69)$.

\section{EFFECT OF THE KGD ON GABAergic AND CHOLINERGIC SYSTEMS DISTURBANCES}

The GABA shunt bypasses two steps of the tricarboxylic acid cycle - the $\alpha$-ketoglutarate (KG) dehydrogenase complex and the succinylCoA synthase - for the conversion of KG into succinate (Figure 1). It involves three enzymes: a GAD, catalyzing the Glu decarboxylation to GABA, a GABA transaminase, converting GABA to SSA, and an SSADH, catalyzing the oxidation of SSA to succinate (97). This metabolic route (the GAD/GABA pathway) is conserved from bacteria, through yeast and plants, to vertebrates. In higher eukaryotes, SSA can be reduced to $\gamma$-hydroxybutyric acid (GHB) by an alternative reaction catalyzed by a GHB dehydrogenase (98-100). It has been proposed that KGD may limit the availability of oxaloacetate to aspartate aminotransferase, an enzyme involved in brain Glu metabolism, resulting in increased Glu or Gln availability to produce GABA (101). The increased conversion of Glu to GABA would be potentially beneficial in ASD (102-105) (Figure 1).

Changes in GABA neurotransmission by KGD might explain the decrease in seizure frequencies and improved behavior observed in Rett syndrome (106). Studies in patients with ASD strongly suggest a dysfunction in the GABAergic system (107109). However, changes in other components (including Gly, taurine, and GABA) cannot be excluded (34). In the case of SSADH deficiency (SSADH), the KGD may work through restitution of GABAergic neurotransmission (36), although the use of KGD in SSADHD has been strongly argued until more research is performed to test its potential detrimental effects in humans (110). Conversely, ketotic rodents fed on KGD showed no changes

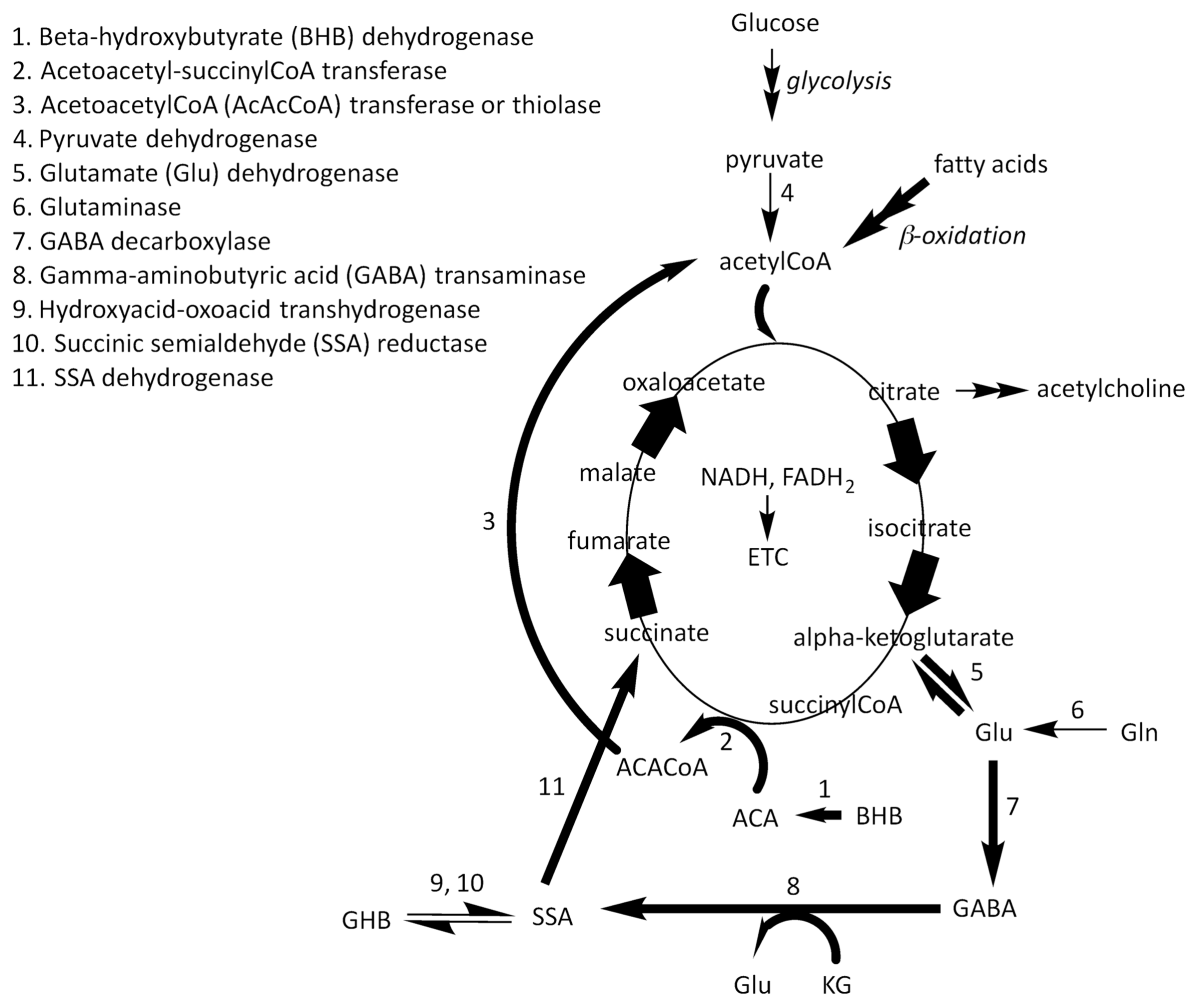

FIGURE 1 | $\beta$-hydroxybutyrate and ACA are utilized as fuel molecules in all mitochondria-containing tissues (except liver). BHB is oxidized to ACA by $\beta$-hydroxybutyrate dehydrogenase at the inner mitochondrial membrane (arrow 1). ACA acquires the CoA moiety from succinylCoA resulting in succinate and acetoacetylCoA (ACACoA; arrow 2). ACACoA releases acetylCoA catalyzed by ACACoA thiolase (arrow 3). AcetylCoA generated from $\beta$-oxidation of fatty acids from the diet and acetylCoA generated by the catabolism of $K B$ is condensed into citrate in the Krebs cycle. The increased flux in the right part of this cycle, increases the concentration of $\alpha$-ketoglutarate (KG) resulting in increases in the production of Glu via glutamate dehydrogenase (arrow 5) or a transaminase (not shown). Glu from these reactions in addition to that formed from the deamination of glutamine (GIn) via glutaminase (arrow 6 ) result in the generation of $\gamma$-aminobutyric acid (GABA). The GABA shunt bypasses two steps of the Krebs cycle - the KG dehydrogenase complex and the succinyl coenzyme $A$ (CoA) synthase - for the conversion of KG into succinate. It involves three enzymes: a Glu decarboxylase (GAD; arrow 7), which catalyzes the decarboxylation of glutamate to GABA, a GABA transaminase (arrow 8), which converts GABA to succinate semialdehyde (SSA), and an SSA dehydrogenase (arrow 11), which catalyzes the oxidation of SSA to succinate. SSA can be reduced to $\gamma$-hydroxybutyric acid (GHB) by an alternative reaction catalyzed by either a hydroxyacid-oxoacid transhydrogenase or SSA reductase (arrows 9, 10). 
in whole brain (GABA) [between brackets = concentrations; $(33$, 111)]; however, regional (GABA) changes cannot be ruled out (112), in addition to species-specific differences in the expression of GABA receptors subtypes $(113,114)$. Considering that cerebrospinal fluid from children treated with KGD showed higher (GABA) (34), it would be of interest to evaluate GABA and amino acid concentrations in different brain areas in animal models of ASD fed KGD.

Dysfunction in the cholinergic system has been observed when $\mathrm{PDH}$ deficits are present (115) because a block in this enzyme decreases (citrate), the precursor of acetylcholine via citrate lyase (116). Studies in humans and animal models of ASD suggested that dysfunction of the cholinergic system underlies ASD-related behavioral symptoms (117-119). Trials conducted on ASD individuals have shown beneficial effects of galantamine (an acetylcholinesterase inhibitor) in the management of aberrant behaviors in children and adolescents with ASD (120-122). Treatment of BTBR mice with the acetylcholinesterase inhibitor donepezil hydrochloride improved social preference, social interaction and decreased cognitive rigidity (123). Thus, a KGD has the potential to exhibit beneficial effects in individuals with both ASD and PDH deficiency because the metabolism of $\mathrm{KB}$ overcomes the decrease in (citrate) (124) and that of (acetylcholine).

\section{POTENTIAL SIDE EFFECTS OF KGD IN ASD}

Several side effects of KGD have been reported, among them: (a) limitation in protein, carbohydrate, and other nutrients intake can result in a lack of weight gain and growth inhibition (42), which could be detrimental in ASD because of a predisposition for being underweight (125) and the presence of eating disorders (126). Thiamine, lipoic acid, and L-carnitine supplementation have been helpful in selected cases (25). (b) Dyslipidemia from KGD (127, 128 ) would need to be supervised in ASD patients with $\beta$-oxidation deficits, including carnitine deficiency $(64,129)$ and, for older patients, the additional increased risk in heart disease and atherosclerosis (130). These patients should limit their fat intake or a modified KGD possibly with carnitine and/or coenzyme Q10 supplementation (131), should be used (132). (c) KGD has an increased risk of systemic ketosis, which may result in lower affinity of hemoglobin for oxygen, resulting in severe outcomes (e.g., coma and death) especially in anemic ASD patients (133). (d) Adverse events experienced by patients with RC complex deficits and epilepsy, which could be extrapolated to those with ASD, included symptomatic persistent hypoglycemia, persistent metabolic acidosis, aspiration pneumonia, and pneumonia followed by respiratory failure (27). (e) Initial fasting and prolonged caloric restriction can cause acute metabolic decompensation in ASD patients with metabolic disorders (134). To reduce the adverse effects of fasting, some studies have omitted the initial fasting period and substituted it with a gradual increase in calories (135). (g) Other side effects include constipation, slower growth, kidney stones, and gastroesophageal reflux (136), although most of them are treatable and/or preventable.

\section{CONCLUDING REMARKS}

More research is necessary to understand the potential therapeutic use of KGD in ASD as discussed at length for SSADHD (110).
More specifically, how this diet may improve mitochondrial function in ASD and how this putative improvement derived from a better energy and/or neurotransmitter management may influence behavioral symptoms. There are concerns about utilizing KGD in patients with metabolic encephalopathies, with specific contraindications in pyruvate carboxylase deficiency, fatty acid oxidation disorders, and Krebs cycle disorders. Thus, given that the mechanism of action of KGD has not been yet fully understood, even in cases of improved behavioral symptoms, KGD in ASD might need to be prescribed on a case-by-case basis, upon careful biochemical characterization and metabolic profiling.

\section{AUTHOR CONTRIBUTIONS}

All authors contributed to the design of the work and interpretation of the literature, drafted the work, and gave final approval of the version to be published. All authors agree to be accountable for all aspects of the work in ensuring that questions related to the accuracy or integrity of any part of the work are appropriately investigated and resolved.

\section{ACKNOWLEDGMENTS}

This work was supported by Simons Foundation (SFARI \#271406 to Cecilia Giulivi), R01-ES011269, R01-ES015359, and R01ES020392.

\section{REFERENCES}

1. Freeman J, Veggiotti P, Lanzi G, Tagliabue A, Perucca E. The ketogenic diet: from molecular mechanisms to clinical effects. Epilepsy Res (2006) 68:145-80. doi:10.1016/j.eplepsyres.2005.10.003

2. Rogovik AL, Goldman RD. Ketogenic diet for treatment of epilepsy. Can Fam Physician (2010) 56:540-2.

3. Freeman JM, Kossoff EH, Hartman AL. The ketogenic diet: one decade later. Pediatrics (2007) 119:535-43. doi:10.1542/peds.2006-2447

4. Kossoff EH, Turner Z, Bluml RM, Pyzik PL, Vining EP. A randomized, crossover comparison of daily carbohydrate limits using the modified Atkins diet. Epilepsy Behav (2007) 10:432-6. doi:10.1016/j.yebeh.2007.01.012

5. Weber S, Molgaard C, Taudorf K, Uldall P. Modified Atkins diet to children and adolescents with medical intractable epilepsy. Seizure (2009) 18:237-40. doi:10.1016/j.seizure.2008.10.004

6. Liu YM, Wang HS. Medium-chain triglyceride ketogenic diet, an effective treatment for drug-resistant epilepsy and a comparison with other ketogenic diets. Biomed J (2013) 36:9-15. doi:10.4103/2319-4170.107154

7. Sankar R, Sotero de Menezes M. Metabolic and endocrine aspects of the ketogenic diet. Epilepsy Res (1999) 37:191-201. doi:10.1016/S0920-1211(99) 00071-6

8. Park S, Kim Da S, Kang S, Daily JW III. A ketogenic diet impairs energy and glucose homeostasis by the attenuation of hypothalamic leptin signaling and hepatic insulin signaling in a rat model of non-obese type 2 diabetes. Exp Biol Med (Maywood) (2011) 236:194-204. doi:10.1258/ebm.2010.010186

9. Ellenbroek JH, Van Dijck L, Tons HA, Rabelink TJ, Carlotti F, Ballieux BE, et al. Long-term ketogenic diet causes glucose intolerance and reduced betaand alpha-cell mass but no weight loss in mice. Am J Physiol Endocrinol Metab (2014) 306:E552-8. doi:10.1152/ajpendo.00453.2013

10. Reichard GA Jr, Haff AC, Skutches CL, Paul P, Holroyde CP, Owen OE. Plasma acetone metabolism in the fasting human. J Clin Invest (1979) 63:619-26. doi:10.1172/JCI109344

11. Musa-Veloso K, Likhodii SS, Rarama E, Benoit S, Liu YM, Chartrand D, et al. Breath acetone predicts plasma ketone bodies in children with epilepsy on a ketogenic diet. Nutrition (2006) 22:1-8. doi:10.1016/j.nut.2005.04.008

12. Halestrap AP. Monocarboxylic acid transport. Compr Physiol (2013) 3:1611-43. doi:10.1002/cphy.c130008

13. Olpin SE. Implications of impaired ketogenesis in fatty acid oxidation disorders. Prostaglandins Leukot Essent Fatty Acids (2004) 70:293-308. doi:10.1016/ j.plefa.2003.06.003 
14. Cheng CM, Kelley B, Wang J, Strauss D, Eagles DA, Bondy CA. A ketogenic diet increases brain insulin-like growth factor receptor and glucose transporter gene expression. Endocrinology (2003) 144:2676-82. doi:10.1210/en.2002-0057

15. Bough KJ, Wetherington J, Hassel B, Pare JF, Gawryluk JW, Greene JG, et al. Mitochondrial biogenesis in the anticonvulsant mechanism of the ketogenic diet. Ann Neurol (2006) 60:223-35. doi:10.1002/ana.20899

16. Noh HS, Lee HP, Kim DW, Kang SS, Cho GJ, Rho JM, et al. A cDNA microarray analysis of gene expression profiles in rat hippocampus following a ketogenic diet. Brain Res Mol Brain Res (2004) 129:80-7. doi:10.1016/j.molbrainres.2004. 06.020

17. DeVivo DC, Leckie MP, Ferrendelli JS, McDougal DB Jr. Chronic ketosis and cerebral metabolism. Ann Neurol (1978) 3:331-7. doi:10.1002/ana.410030410

18. Kim do Y, Vallejo J, Rho JM. Ketones prevent synaptic dysfunction induced by mitochondrial respiratory complex inhibitors. J Neurochem (2010) 114:130-41. doi:10.1111/j.1471-4159.2010.06728.x

19. Tieu K, Perier C, Caspersen C, Teismann P, Wu DC, Yan SD, et al. DBeta-hydroxybutyrate rescues mitochondrial respiration and mitigates features of Parkinson disease. J Clin Invest (2003) 112:892-901. doi:10.1172/ JCI200318797

20. Hughes SD, Kanabus M, Anderson G, Hargreaves IP, Rutherford T, O’Donnell $\mathrm{M}$, et al. The ketogenic diet component decanoic acid increases mitochondrial citrate synthase and complex I activity in neuronal cells. J Neurochem (2014) 129:426-33. doi:10.1111/jnc.12646

21. McDaniel SS, Rensing NR, Thio LL, Yamada KA, Wong M. The ketogenic diet inhibits the mammalian target of rapamycin (mTOR) pathway. Epilepsia (2011) 52:e7-11. doi:10.1111/j.1528-1167.2011.02981.x

22. Wijburg FA, Barth PG, Bindoff LA, Birch-Machin MA, Van Der Blij JF, Ruitenbeek W, et al. Leigh syndrome associated with a deficiency of the pyruvate dehydrogenase complex: results of treatment with a ketogenic diet. Neuropediatrics (1992) 23:147-52. doi:10.1055/s-2008-1071331

23. Barnerias C, Saudubray JM, Touati G, De Lonlay P, Dulac O, Ponsot G, et al. Pyruvate dehydrogenase complex deficiency: four neurological phenotypes with differing pathogenesis. Dev Med Child Neurol (2010) 52:e1-9. doi:10.1111/j.1469-8749.2009.03541.x

24. Di Pisa V, Cecconi I, Gentile V, Di Pietro E, Marchiani V, Verrotti A, et al. Case report of pyruvate dehydrogenase deficiency with unusual increase of fats during ketogenic diet treatment. J Child Neurol (2012) 27:1593-6. doi:10.1177/0883073812436424

25. Wexler ID, Hemalatha SG, McConnell J, Buist NR, Dahl HH, Berry SA, et al. Outcome of pyruvate dehydrogenase deficiency treated with ketogenic diets. Studies in patients with identical mutations. Neurology (1997) 49:1655-61. doi:10.1212/WNL.49.6.1655

26. El-Gharbawy AH, Boney A, Young SP, Kishnani PS. Follow-up of a child with pyruvate dehydrogenase deficiency on a less restrictive ketogenic diet. Mol Genet Metab (2011) 102:214-5. doi:10.1016/j.ymgme.2010.11.001

27. Kang HC, Lee YM, Kim HD, Lee JS, Slama A. Safe and effective use of the ketogenic diet in children with epilepsy and mitochondrial respiratory chain complex defects. Epilepsia (2007) 48:82-8. doi:10.1111/j.1528-1167.2006.00906.x

28. Sullivan PG, Rippy NA, Dorenbos K, Concepcion RC, Agarwal AK, Rho JM. The ketogenic diet increases mitochondrial uncoupling protein levels and activity. Ann Neurol (2004) 55:576-80. doi:10.1002/ana.20062

29. Milder JB, Liang LP, Patel M. Acute oxidative stress and systemic Nrf2 activation by the ketogenic diet. Neurobiol Dis (2010) 40:238-44. doi:10.1016/j.nbd. 2010.05.030

30. Ziegler DR, Ribeiro LC, Hagenn M, Siqueira IR, Araujo E, Torres IL, et al. Ketogenic diet increases glutathione peroxidase activity in rat hippocampus. Neurochem Res (2003) 28:1793-7. doi:10.1023/A:1026107405399

31. Jarrett SG, Milder JB, Liang LP, Patel M. The ketogenic diet increases mitochondrial glutathione levels. J Neurochem (2008) 106:1044-51. doi:10.1111/j. 1471-4159.2008.05460.x

32. Maalouf M, Sullivan PG, Davis L, Kim DY, Rho JM. Ketones inhibit mitochondrial production of reactive oxygen species production following glutamate excitotoxicity by increasing NADH oxidation. Neuroscience (2007) 145:256-64. doi:10.1016/j.neuroscience.2006.11.065

33. Yudkoff M, Daikhin Y, Nissim I, Horyn O, Lazarow A, Luhovyy B, et al. Response of brain amino acid metabolism to ketosis. Neurochem Int (2005) 47:119-28. doi:10.1016/j.neuint.2005.04.014

34. Dahlin M, Elfving A, Ungerstedt U, Åmark P. The ketogenic diet influences the levels of excitatory and inhibitory amino acids in the CSF in children with refractory epilepsy. Epilepsy Res (2005) 64:115-25. doi:10.1016/j.eplepsyres. 2005.03.008

35. Maurer CM, Schonthaler HB, Mueller KP, Neuhauss SC. Distinct retinal deficits in a zebrafish pyruvate dehydrogenase-deficient mutant. J Neurosci (2010) 30:11962-72. doi:10.1523/JNEUROSCI.2848-10.2010

36. Nylen K, Velazquez JL, Likhodii SS, Cortez MA, Shen L, Leshchenko Y, et al. A ketogenic diet rescues the murine succinic semialdehyde dehydrogenase deficient phenotype. Exp Neurol (2008) 210:449-57. doi:10.1016/j.expneurol.2007. 11.015

37. Baranano KW, Hartman AL. The ketogenic diet: uses in epilepsy and other neurologic illnesses. Curr Treat Options Neurol (2008) 10:410-9. doi:10.1007/ s11940-008-0043-8

38. Stafstrom CE, Rho JM. The ketogenic diet as a treatment paradigm for diverse neurological disorders. Front Pharmacol (2012) 3:59. doi:10.3389/fphar.2012. 00059

39. Hartman AL, Gasior M, Vining EP, Rogawski MA. The neuropharmacology of the ketogenic diet. Pediatr Neurol (2007) 36:281-92. doi:10.1016/j. pediatrneurol.2007.02.008

40. Kossoff EH, Wang HS. Dietary therapies for epilepsy. Biomed J (2013) 36:2-8. doi: 10.4103/2319-4170.107152

41. Marsh EB, Freeman JM, Kossoff EH, Vining EP, Rubenstein JE, Pyzik PL, et al. The outcome of children with intractable seizures: a 3- to 6-year follow-up of 67 children who remained on the ketogenic diet less than one year. Epilepsia (2006) 47:425-30. doi:10.1111/j.1528-1167.2006.00439.x

42. Coppola G, Verrotti A, Ammendola E, Operto FF, Corte RD, Signoriello G, et al. Ketogenic diet for the treatment of catastrophic epileptic encephalopathies in childhood. Eur J Paediatr Neurol (2010) 14:229-34. doi:10.1016/j.ejpn.2009. 06.006

43. Bough KJ, Rho JM. Anticonvulsant mechanisms of the ketogenic diet. Epilepsia (2007) 48:43-58. doi:10.1111/j.1528-1167.2007.00915.x

44. Giulivi C, Zhang YF, Omanska-Klusek A, Ross-Inta C, Wong S, Hertz-Picciotto I, et al. Mitochondrial dysfunction in autism. JAMA (2010) 304:2389-96. doi:10.1001/jama.2010.1706

45. Hallmayer J, Cleveland S, Torres A, Phillips J, Cohen B, Torigoe T, et al. Genetic heritability and shared environmental factors among twin pairs with autism. Arch Gen Psychiatry (2011) 68:1095-102. doi:10.1001/archgenpsychiatry.2011. 76

46. Frazier TW, Thompson L, Youngstrom EA, Law P, Hardan AY, Eng C, et al. A twin study of heritable and shared environmental contributions to autism. J Autism Dev Disord (2014). doi:10.1007/s10803-014-2081-2

47. Holmboe K, Rijsdijk FV, Hallett V, Happe F, Plomin R, Ronald A. Strong genetic influences on the stability of autistic traits in childhood. J Am Acad Child Adolesc Psychiatry (2014) 53:221-30. doi:10.1016/j.jaac.2013.11.001

48. Zecavati N, Spence SJ. Neurometabolic disorders and dysfunction in autism spectrum disorders. Curr Neurol Neurosci Rep (2009) 9:129-36. doi:10.1007/ s11910-009-0021-x

49. Bolton PF, Carcani-Rathwell I, Hutton J, Goode S, Howlin P, Rutter M. Epilepsy in autism: features and correlates. Br J Psychiatry (2011) 198:289-94. doi:10.1192/bjp.bp.109.076877

50. Tuchman R, Cuccaro M, Alessandri M. Autism and epilepsy: historical perspective. Brain Dev (2010) 32:709-18. doi:10.1016/j.braindev.2010.04.008

51. Li BM, Liu XR, Yi YH, Deng YH, Su T, Zou X, et al. Autism in Dravet syndrome: prevalence, features, and relationship to the clinical characteristics of epilepsy and mental retardation. Epilepsy Behav (2011) 21:291-5. doi:10.1016/j.yebeh.2011.04.060

52. Bujas-Petkovic Z, Matijasic R, Divcic B. Rett's syndrome-differential diagnosis of autism in a case report. Lijec Vjesn (1989) 111:458-60.

53. Steffenburg U, Hagberg G, Hagberg B. Epilepsy in a representative series of Rett syndrome. Acta Paediatr (2001) 90:34-9. doi:10.1111/j.1651-2227.2001. tb00252.x

54. Evangeliou A, Vlachonikolis I, Mihailidou H, Spilioti M, Skarpalezou A, Makaronas N, et al. Application of a ketogenic diet in children with autistic behavior: pilot study. J Child Neurol (2003) 18:113-8. doi:10.1177/ 08830738030180020501

55. Herbert MR, Buckley JA. Autism and dietary therapy: case report and review of the literature. J Child Neurol (2013) 28:975-82. doi:10.1177/ 0883073813488668

56. Mantis JG, Fritz CL, Marsh J, Heinrichs SC, Seyfried TN. Improvement in motor and exploratory behavior in Rett syndrome mice with restricted 
ketogenic and standard diets. Epilepsy Behav (2009) 15:133-41. doi:10.1016/j. yebeh.2009.02.038

57. Ruskin DN, Svedova J, Cote JL, Sandau U, Rho JM, Kawamura M Jr, et al. Ketogenic diet improves core symptoms of autism in BTBR mice. PLoS One (2013) 8:e65021. doi:10.1371/journal.pone.0065021

58. Johnston CS, Tjonn SL, Swan PD, White A, Hutchins H, Sears B. Ketogenic low-carbohydrate diets have no metabolic advantage over nonketogenic lowcarbohydrate diets. Am J Clin Nutr (2006) 83:1055-61. doi:10.1371/journal. pone. 0065021

59. Veggiotti P, Teutonico F, Alfei E, Nardocci N, Zorzi G, Tagliabue A, et al. Glucose transporter type 1 deficiency: ketogenic diet in three patients with atypical phenotype. Brain Dev (2010) 32:404-8. doi:10.1016/j.braindev.2009. 04.013

60. Prasad C, Rupar T, Prasad AN. Pyruvate dehydrogenase deficiency and epilepsy. Brain Dev (2011) 33:856-65. doi:10.1016/j.braindev.2011.08.003

61. Morris AA, Leonard JV. The treatment of congenital lactic acidoses. J Inherit Metab Dis (1996) 19:573-80. doi:10.1007/BF01799117

62. Clark-Taylor T, Clark-Taylor BE. Is autism a disorder of fatty acid metabolism? Possible dysfunction of mitochondrial beta-oxidation by long chain acylCoA dehydrogenase. Med Hypotheses (2004) 62:970-5. doi:10.1016/j.mehy. 2004.01.011

63. Frye RE, Melnyk S, MacFabe DF. Unique acyl-carnitine profiles are potential biomarkers for acquired mitochondrial disease in autism spectrum disorder. Transl Psychiatry (2013) 3:e220. doi:10.1038/tp.2012.143

64. Celestino-Soper PB, Violante S, Crawford EL, Luo R, Lionel AC, Delaby E, et al. A common X-linked inborn error of carnitine biosynthesis may be a risk factor for nondysmorphic autism. Proc Natl Acad Sci U S A (2012) 109:7974-81. doi:10.1073/pnas.1120210109

65. Ahola-Erkkila S, Carroll CJ, Peltola-Mjosund K, Tulkki V, Mattila I, SeppanenLaakso $\mathrm{T}$, et al. Ketogenic diet slows down mitochondrial myopathy progression in mice. Hum Mol Genet (2010) 19:1974-84. doi:10.1093/hmg/ddq076

66. Bernier FP, Boneh A, Dennett X, Chow CW, Cleary MA, Thorburn DR. Diagnostic criteria for respiratory chain disorders in adults and children. Neurology (2002) 59:1406-11. doi:10.1212/01.WNL.0000033795.17156.00

67. Rossignol R, Malgat M, Mazat JP, Letellier T. Threshold effect and tissue specificity. Implication for mitochondrial cytopathies. J Biol Chem (1999) 274:33426-32. doi:10.1074/jbc.274.47.33426

68. Napoli E, Wong S, Giulivi C. Evidence of reactive oxygen species-mediated damage to mitochondrial DNA in children with typical autism. Mol Autism (2013) 4:2. doi:10.1186/2040-2392-4-2

69. Napoli E, Wong S, Hertz-Picciotto I, Giulivi C. Deficits in bioenergetics and impaired immune response in granulocytes from children with autism. Pediatrics (2014). doi:10.1542/peds.2013-1545

70. Yoneda M, Chomyn A, Martinuzzi A, Hurko O, Attardi G. Marked replicative advantage of human mtDNA carrying a point mutation that causes the MELAS encephalomyopathy. Proc Natl Acad Sci U S A (1992) 89:11164-8. doi:10.1073/pnas.89.23.11164

71. Diaz F, Bayona-Bafaluy MP, Rana M, Mora M, Hao H, Moraes CT. Human mitochondrial DNA with large deletions repopulates organelles faster than fulllength genomes under relaxed copy number control. Nucleic Acids Res (2002) 30:4626-33. doi:10.1093/nar/gkf602

72. Santra S, Gilkerson RW, Davidson M, Schon EA. Ketogenic treatment reduces deleted mitochondrial DNAs in cultured human cells. Ann Neurol (2004) 56:662-9. doi:10.1002/ana.20240

73. Weissman JR, Kelley RI, Bauman ML, Cohen BH, Murray KF, Mitchell RL, et al. Mitochondrial disease in autism spectrum disorder patients: a cohort analysis. PLoS One (2008) 3:e3815. doi:10.1371/journal.pone.0003815

74. Rossignol DA, Frye RE. Mitochondrial dysfunction in autism spectrum disorders: a systematic review and meta-analysis. Mol Psychiatry (2012) 17:290-314. doi:10.1038/mp.2010.136

75. Rossignol DA, Frye RE. A review of research trends in physiological abnormalities in autism spectrum disorders: immune dysregulation, inflammation, oxidative stress, mitochondrial dysfunction and environmental toxicant exposures. Mol Psychiatry (2012) 17:389-401. doi:10.1038/mp.2011.165

76. Gu F, Chauhan V, Kaur K, Brown WT, Lafauci G, Wegiel J, et al. Alterations in mitochondrial DNA copy number and the activities of electron transport chain complexes and pyruvate dehydrogenase in the frontal cortex from subjects with autism. Transl Psychiatry (2013) 3:e299. doi:10.1038/tp.2013.68
77. Milder J, Patel M. Modulation of oxidative stress and mitochondrial function by the ketogenic diet. Epilepsy Res (2012) 100:295-303. doi:10.1016/j.eplepsyres. 2011.09.021

78. Finsterer J, Zarrouk Mahjoub S. Epilepsy in mitochondrial disorders. Seizure (2012) 21:316-21. doi:10.1016/j.seizure.2012.03.003

79. Werther GA, Russo V, Baker N, Butler G. The role of the insulin-like growth factor system in the developing brain. Horm Res (1998) 49(Suppl 1):37-40. doi:10.1159/000053066

80. Carro E, Trejo JL, Núñez A, Torres-Aleman I. Brain repair and neuroprotection by serum insulin-like growth factor I. Mol Neurobiol (2003) 27:153-62. doi:10.1385/MN:27:2:153

81. Gasparini L, Xu H. Potential roles of insulin and IGF-1 in Alzheimer's disease. Trends Neurosci (2003) 26:404-6. doi:10.1016/S0166-2236(03)00163-2

82. Zhao Y, Fung C, Shin D, Shin BC, Thamotharan S, Sankar R, et al. Neuronal glucose transporter isoform 3 deficient mice demonstrate features of autism spectrum disorders. Mol Psychiatry (2010) 15:286-99. doi:10.1038/mp.2009.51

83. Chen J, Alberts I, Li X. Dysregulation of the IGF-I/PI3K/AKT/mTOR signaling pathway in autism spectrum disorders. Int J Dev Neurosci (2014) 35C:35-41. doi:10.1016/j.ijdevneu.2014.03.006

84. Gano L, Patel M, Rho JM. Ketogenic diets, mitochondria and neurological diseases. J Lipid Res (2014). doi:10.1194/jlr.R048975

85. Kelleher RJ III, Bear MF. The autistic neuron: troubled translation? Cell (2008) 135:401-6. doi:10.1016/j.cell.2008.10.017

86. Sawicka K, Zukin RS. Dysregulation of mTOR signaling in neuropsychiatric disorders: therapeutic implications. Neuropsychopharmacology (2012) 37:305-6. doi:10.1038/npp.2011.210

87. Gkogkas CG, Khoutorsky A, Ran I, Rampakakis E, Nevarko T, Weatherill DB, et al. Autism-related deficits via dysregulated eIF4E-dependent translational control. Nature (2013) 493:371-7. doi:10.1038/nature11628

88. Gottlieb RA, Carreira RS. Autophagy in health and disease. 5. Mitophagy as a way of life. Am J Physiol Cell Physiol (2010) 299:C203-10. doi:10.1152/ajpcell. 00097.2010

89. Napoli E, Ross-Inta C, Wong S, Hung C, Fujisawa Y, Sakaguchi D, et al. Mitochondrial dysfunction in Pten haplo-insufficient mice with social deficits and repetitive behavior: interplay between Pten and p53. PLoS One (2012) 7:e42504. doi:10.1371/journal.pone.0042504

90. Wong M. Mammalian target of rapamycin (mTOR) pathways in neurological diseases. Biomed J (2013) 36:40-50. doi:10.4103/2319-4170.110365

91. Coleman ST, Fang TK, Rovinsky SA, Turano FJ, Moye-Rowley WS. Expression of a glutamate decarboxylase homologue is required for normal oxidative stress tolerance in Saccharomyces cerevisiae. J Biol Chem (2001) 276:244-50. doi:10.1074/jbc.M007103200

92. Erasmus DJ, Van Der Merwe GK, Van Vuuren HJ. Genome-wide expression analyses: metabolic adaptation of Saccharomyces cerevisiae to high sugar stress. FEMS Yeast Res (2003) 3:375-99. doi:10.1016/S1567-1356(02)00203-9

93. Cakir T, Patil KR, Onsan Z, Ulgen KO, Kirdar B, Nielsen J. Integration of metabolome data with metabolic networks reveals reporter reactions. Mol Syst Biol (2006) 2:50. doi:10.1038/msb4100085

94. Schonfeld P, Wieckowski MR, Lebiedzinska M, Wojtczak L. Mitochondrial fatty acid oxidation and oxidative stress: lack of reverse electron transferassociated production of reactive oxygen species. Biochim Biophys Acta (2010) 1797:929-38. doi:10.1016/j.bbabio.2010.01.010

95. James SJ, Melnyk S, Fuchs G, Reid T, Jernigan S, Pavliv O, et al. Efficacy of methylcobalamin and folinic acid treatment on glutathione redox status in children with autism. Am J Clin Nutr (2009) 89:425-30. doi:10.3945/ajcn.2008. 26615

96. James SJ, Rose S, Melnyk S, Jernigan S, Blossom S, Pavliv O, et al. Cellular and mitochondrial glutathione redox imbalance in lymphoblastoid cells derived from children with autism. FASEB J (2009) 23:2374-83. doi:10.1096/fj.08128926

97. Ramos F, El Guezzar M, Grenson M, Wiame JM. Mutations affecting the enzymes involved in the utilization of 4-aminobutyric acid as nitrogen source by the yeast Saccharomyces cerevisiae. Eur J Biochem (1985) 149:401-4. doi:10.1111/j.1432-1033.1985.tb08939.x

98. Andriamampandry C, Siffert JC, Schmitt M, Garnier JM, Staub A, Muller C, et al. Cloning of a rat brain succinic semialdehyde reductase involved in the synthesis of the neuromodulator gamma-hydroxybutyrate. Biochem J (1998) 334(Pt 1):43-50. 
99. Schaller M, Schaffhauser M, Sans N, Wermuth B. Cloning and expression of succinic semialdehyde reductase from human brain. Identity with aflatoxin B1 aldehyde reductase. Eur J Biochem (1999) 265:1056-60. doi:10.1046/j.14321327.1999.00826.x

100. Breitkreuz KE, Allan WL, Van Cauwenberghe OR, Jakobs C, Talibi D, Andre $\mathrm{B}$, et al. A novel gamma-hydroxybutyrate dehydrogenase: identification and expression of an Arabidopsis cDNA and potential role under oxygen deficiency. J Biol Chem (2003) 278:41552-6. doi:10.1074/jbc.M305717200

101. Yudkoff M, Daikhin Y, Melø TM, Nissim I, Sonnewald U, Nissim I. The ketogenic diet and brain metabolism of amino acids: relationship to the anticonvulsant effect. Annu Rev Nutr (2007) 27:415-30. doi:10.1146/annurev.nutr.27. 061406.093722

102. Chattopadhyaya B, Cristo GD. GABAergic circuit dysfunctions in neurodevelopmental disorders. Front Psychiatry (2012) 3:51. doi:10.3389/fpsyt.2012. 00051

103. Han S, Tai C, Westenbroek RE, Yu FH, Cheah CS, Potter GB, et al. Autistic-like behaviour in Scnla \pm mice and rescue by enhanced GABA-mediated neurotransmission. Nature (2012) 489:385-90. doi:10.1038/nature11356

104. Weston MC, Chen H, Swann JW. Multiple roles for mammalian target of rapamycin signaling in both glutamatergic and GABAergic synaptic transmission. J Neurosci (2012) 32:11441-52. doi:10.1523/JNEUROSCI.1283-12. 2012

105. Banerjee A, Garcia-Oscos F, Roychowdhury S, Galindo LC, Hall S, Kilgard MP, et al. Impairment of cortical GABAergic synaptic transmission in an environmental rat model of autism. Int J Neuropsychopharmacol (2013) 16:1309-18. doi:10.1017/S1461145712001216

106. Liebhaber GM, Riemann E, Baumeister FA. Ketogenic diet in Rett syndrome. J Child Neurol (2003) 18:74-5. doi:10.1177/08830738030180011801

107. Fatemi SH, Halt AR, Stary JM, Kanodia R, Schulz SC, Realmuto GR. Glutamic acid decarboxylase 65 and $67 \mathrm{kDa}$ proteins are reduced in autistic parietal and cerebellar cortices. Biol Psychiatry (2002) 52:805-10. doi:10.1016/S00063223(02)01430-0

108. Collins AL, Ma DQ, Whitehead PL, Martin ER, Wright HH, Abramson RK, et al. Investigation of autism and GABA receptor subunit genes in multiple ethnic groups. Neurogenetics (2006) 7:167-74. doi:10.1007/s10048-006-0045-1

109. Fatemi SH, Reutiman TJ, Folsom TD, Thuras PD. GABA(A) receptor downregulation in brains of subjects with autism. J Autism Dev Disord (2009) 39:223-30. doi:10.1007/s10803-008-0646-7

110. Knerr I, Pearl PL. Ketogenic diet: stoking energy stores and still posing questions. Exp Neurol (2008) 211:11-3. doi:10.1016/j.expneurol.2008.01.015

111. Al-Mudallal AS, Lamanna JC, Lust WD, Harik SI. Diet-induced ketosis does not cause cerebral acidosis. Epilepsia (1996) 37:258-61. doi:10.1111/j.1528-1157. 1996.tb00022.x

112. Nordli DR Jr, De Vivo DC. The ketogenic diet revisited: back to the future. Epilepsia (1997) 38:743-9. doi:10.1111/j.1528-1157.1997.tb01460.x

113. Nguyen Q, Sapp DW, Van Ness PC, Olsen RW. Modulation of GABAA receptor binding in human brain by neuroactive steroids: species and brain regional differences. Synapse (1995) 19:77-87. doi:10.1002/syn.890190203

114. Mendu SK, Bhandage A, Jin Z, Birnir B. Different subtypes of GABA-A receptors are expressed in human, mouse and rat T lymphocytes. PLoS One (2012) 7:e42959. doi:10.1371/journal.pone.0042959

115. Imahori K, Uchida T. Physiology and pathology of tau protein kinases in relation to Alzheimer's disease. J Biochem (1997) 121:179-88.

116. Veech RL, Chance B, Kashiwaya Y, Lardy HA, Cahill GF Jr. Ketone bodies, potential therapeutic uses. IUBMB Life (2001) 51:241-7. doi:10.1080/ 152165401753311780

117. Kemper TL, Bauman M. Neuropathology of infantile autism. J Neuropathol Exp Neurol (1998) 57:645-52. doi:10.1097/00005072-199807000-00001

118. Sokol DK, Dunn DW, Edwards-Brown M, Feinberg J. Hydrogen proton magnetic resonance spectroscopy in autism: preliminary evidence of elevated choline/creatine ratio. J Child Neurol (2002) 17:245-9. doi:10.1177/ 088307380201700401

119. Deutsch SI, Urbano MR, Neumann SA, Burket JA, Katz E. Cholinergic abnormalities in autism: is there a rationale for selective nicotinic agonist interventions? Clin Neuropharmacol (2010) 33:114-20. doi:10.1097/WNF. 0b013e3181d6f7ad
120. Niederhofer H, Staffen W, Mair A. Galantamine may be effective in treating autistic disorder. BMJ (2002) 325:1422. doi:10.1136/bmj.325.7377.1422/a

121. Nicolson R, Craven-Thuss B, Smith J. A prospective, open-label trial of galantamine in autistic disorder. J Child Adolesc Psychopharmacol (2006) 16:621-9. doi:10.1089/cap.2006.16.621

122. Ghaleiha A, Ghyasvand M, Mohammadi MR, Farokhnia M, Yadegari N, Tabrizi $\mathrm{M}$, et al. Galantamine efficacy and tolerability as an augmentative therapy in autistic children: a randomized, double-blind, placebo-controlled trial. J Psychopharmacol (2013) 28:677-85. doi:10.1177/0269881113508830

123. Karvat G, Kimchi T. Acetylcholine elevation relieves cognitive rigidity and social deficiency in a mouse model of autism. Neuropsychopharmacology (2014) 39:831-40. doi:10.1038/npp.2013.274

124. Sato K, Kashiwaya Y, Keon CA, Tsuchiya N, King MT, Radda GK, et al. Insulin, ketone bodies, and mitochondrial energy transduction. FASEB J (1995) 9:651-8.

125. Sobanski E, Marcus A, Hennighausen K, Hebebrand J, Schmidt MH. Further evidence for a low body weight in male children and adolescents with Asperger's disorder. Eur Child Adolesc Psychiatry (1999) 8:312-4. doi:10.1007/ s007870050106

126. Fisman S, Steele M, Short J, Byrne T, Lavallee C. Case study: anorexia nervosa and autistic disorder in an adolescent girl. J Am Acad Child Adolesc Psychiatry (1996) 35:937-40. doi:10.1097/00004583-199607000-00021

127. Kwiterovich PO Jr, Vining EPG, Pyzik P, Skolasky R Jr, Freeman JM. Effect of a high-fat ketogenic diet on plasma levels of lipids, lipoproteins, and apolipoproteins in children. JAMA (2003) 290:912-20. doi:10.1001/jama.290.7.912

128. Nizamuddin J, Turner Z, Rubenstein JE, Pyzik PL, Kossoff EH. Management and risk factors for dyslipidemia with the ketogenic diet. J Child Neurol (2008) 23:758-61. doi:10.1177/0883073808318061

129. Liebhaber G, Pascher B, Gempel K, Baumeister FA. Asymptomatic carnitine depletion on ketogenic diet in patients with pharmacoresistant epilepsies. Klin Padiatr (2006) 218:260-3. doi:10.1055/s-2005-836811

130. Fukao T, Mitchell G, Sass JO, Hori T, Orii K, Aoyama Y. Ketone body metabolism and its defects. J Inherit Metab Dis (2014). doi:10.1007/s10545-014-9704-9

131. Parikh S, Saneto R, Falk MJ, Anselm I, Cohen BH, Haas R, et al. A modern approach to the treatment of mitochondrial disease. Curr Treat Options Neurol (2009) 11:414-30. doi:10.1007/s11940-009-0046-0

132. Kossoff EH, Zupec-Kania BA, Rho JM. Ketogenic diets: an update for child neurologists. J Child Neurol (2009) 24:979-88. doi:10.1177/0883073809337162

133. Latif A, Heinz P, Cook R. Iron deficiency in autism and Asperger syndrome. Autism (2002) 6:103-14. doi:10.1177/1362361302006001008

134. Kang HC, Chung DE, Kim DW, Kim HD. Early- and late-onset complications of the ketogenic diet for intractable epilepsy. Epilepsia (2004) 45:1116-23. doi:10.1111/j.0013-9580.2004.10004.x

135. Kim YM, Vaidya VV, Khusainov T, Kim HD, Kim SH, Lee EJ, et al. Various indications for a modified Atkins diet in intractable childhood epilepsy. Brain $\operatorname{Dev}$ (2012) 34:570-5. doi:10.1016/j.braindev.2011.09.013

136. Jozwiak S, Kossoff EH, Kotulska-Jozwiak K. Dietary treatment of epilepsy: rebirth of an ancient treatment. Neurol Neurochir Pol (2011) 45:370-8. doi:10.1016/S0028-3843(14)60108-0

Conflict of Interest Statement: The authors declare that the research was conducted in the absence of any commercial or financial relationships that could be construed as a potential conflict of interest.

Received: 30 May 2014; accepted: 17 June 2014; published online: 30 June 2014. Citation: Napoli E, Dueñas $N$ and Giulivi C (2014) Potential therapeutic use of the ketogenic diet in autism spectrum disorders. Front. Pediatr. 2:69. doi: 10.3389/fped.2014.00069

This article was submitted to Child and Neurodevelopmental Psychiatry, a section of the journal Frontiers in Pediatrics.

Copyright (C) 2014 Napoli, Dueñas and Giulivi. This is an open-access article distributed under the terms of the Creative Commons Attribution License (CC BY). The use, distribution or reproduction in other forums is permitted, provided the original author(s) or licensor are credited and that the original publication in this journal is cited, in accordance with accepted academic practice. No use, distribution or reproduction is permitted which does not comply with these terms. 